\begin{tabular}{|l|c|c|c|r|}
\hline $\begin{array}{l}\text { Cuadernos de Investigación Geográfica } \\
\text { Geographical Research Letters }\end{array}$ & 2018 & N $^{\circ} 44(2)$ & pp. 615-640 & $\begin{array}{r}\text { ISSN 0211-6820 } \\
\text { eISSN 1697-9540 }\end{array}$ \\
\hline
\end{tabular}

\title{
APPLICATION OF A DISTRIBUTED 2D OVERLAND FLOW MODEL FOR RAINFALL/RUNOFF AND EROSION SIMULATION IN A MEDITERRANEAN WATERSHED
}

\author{
C. JUEZ ${ }^{1 *}$, A. TENA $^{2}$, J. FERNÁNDEZ-PATO ${ }^{1}$, \\ R.J. BATALLA ${ }^{2,3}$, P. GARCÍA-NAVARRO ${ }^{1}$ \\ ${ }^{1}$ LIFTEC (CSIC) - Universidad de Zaragoza, Zaragoza, Spain. \\ ${ }^{2}$ Environmental and Soil Sciences, RIUS, Universidad de Lérida, Lérida, Spain. \\ ${ }^{3}$ Catalan Institute for Water Research, Gerona, Spain.
}

\begin{abstract}
Soil erosion has reemerged as an environmental problem associated with climate change that requires the help of simulation tools for forecasting future consequences. This topic becomes even more relevant in Mediterranean catchments due to the highly variable and irregular rainfall regime. Hence, an approach that includes the rainfall/runoff and erosion phenomena is required for quantifying the amount of soil the catchments are transferring to the rivers. As the calibration process of the infiltration and erosion parameters can become cumbersome in terms of iterations to the optimal values to fit experimental data, a Simplified Catchment Model (SCM) is introduced as a first approach. The set of tuning constants that provides the best fit are used as input for re-calibrating the parameters by means of the simulation of the real catchment. The modeling effort here presented opens its application to the analysis of the hydro-sedimentary processes at larger temporal and spatial scales.
\end{abstract}

Aplicación de un modelo distribuido 2D para simular la transformación de lluvia en escorrentía y la erosión del suelo en una cuenca mediterránea

RESUMEN. La erosión de suelos ha vuelto a emerger como un problema medio ambiental asociado con el cambio climático que requiere de herramientas de simulación que ayuden en la predicción de futuras consecuencias. Este problema medio ambiental es incluso más relevante en las cuencas mediterráneas, debido a las precipitaciones variables e irregulares. Por todo ello, se requiere de una herramienta de simulación que incluya la lluvia, escorrentía y erosión de suelos para así determinar cuáles son los aportes sedimentarios de la cuenca al río. Puesto que el proceso de calibración de la cuenca para los parámetros de infiltración y erosión puede ser tedioso debido al alto número de iteraciones requerido hasta alcanzar un resultado satisfactorio, en este trabajo se presenta un modelo de cuenca simplificado (SCM) que acelera dicha calibración. Los parámetros calibrados en la cuenca simplificada son utilizados para guiar de manera 
efectiva la calibración de la cuenca real. El modelo numérico y la estrategia de calibración aquí presentados constituyen un primer paso para abordar proyectos más ambiciosos en donde investigar los efectos combinados de la hidrología y la erosión de suelos para grandes escalas temporales y espaciales.

Key words: soil erosion, 2D overland modeling, Mediterranean watershed, calibration, finite volume.

Palabras clave: erosión de suelos, modelización 2D de escorrentía, cuenca mediterránea, calibración, volúmenes finitos.

*Corresponding autor: C. Juez, LIFTEC (CSIC) - Universidad de Zaragoza, Zaragoza, Spain.E-mail address: carmelo@unizar.es

\section{Introduction}

In the last decades, the scientific interest in soil erosion has increased due to the growing awareness of its associated impacts. Quantification of sediment transport is fundamental to understand the global patterns of land denudation and sediment delivery. In this context, the elaboration of sediment yields and budgets provides an effective basis for quantifying and representing the key components of the sediment delivery system within a catchment, such as the fluvial sediment transport component (Owens, 2005; Schleiss et al., 2016).

Whilst soil erosion and redistribution in tropical and semiarid areas is still a significant issue, in temperate areas it is being increasingly recognized as a hazard. These issues are of particular importance for Mediterranean areas, because of the irregular or torrential rainfall regime. Annual precipitation tends to be concentrated in extreme rainfalls sometimes reaching the order of hundreds of $\mathrm{mm} \mathrm{d}^{-1}$ (Mariani and Parisi, 2014), favoring large erosion during flush events of high intensity. Generally, climate change projections point to an exacerbation of this extreme character, modifying the magnitude and frequency of extreme weather events such as flooding and droughts (Lehner et al., 2006). At present, one of the main concerns of soil erosion research throughout the world is the assessment of climate change impact on the sediment cycle (e.g. Mullan et al., 2012). It is well known the sensitivity of the Mediterranean region to environmental changes (e.g. Conacher and Sala, 1994), thus there is still the need of sediment transport studies tackling the effects of these changes on hydrological and erosional processes; however, this type of studies are often difficult to carry out due to the difficulty of studying infrequent erosional events in temporary rivers (e.g. Gallart et al., 2008a). Therefore, and despite the series of studies done so far, there is a significant gap in our understanding of soil erosion processes and the associated sediment yield in this region (e.g. Batalla and Sala, 1996; Verdú et al., 2000; GarcíaRuíz and Poesen, 2007; Nord and Esteves, 2010; Nadal-Romero et al., 2015; Buendia 
et al., 2016) as well as the ecological and basin-hydromorphological impacts (Rovira and Batalla, 2006; Buendía et al., 2014; Gumiere et al., 2014), as well as for fluvial sediment management, i.e. data and models used by water and environmental agencies to support their conservation and rehabilitation actions in rivers (e.g. Brierley and Fryirs, 2008).

A common way to assess and forecast sediment production and transport is through a mathematical modeling approach (Harmon and Doe, 2001). Recent reviews highlighted the development of empirical and physically based distributed models (see Merritt et al., 2003, Aksoy, 2005, Gallart et al., 2008b for TOPMODEL; Francke et al., 2008 for the Non-parametric method; Delgado et al., 2010 for the HYLUC model; Bronstert et al., 2014 for the WASA model; Bussi et al., 2014 for TETIS; Molina-Navarro et al., 2014 for SWAT model). For instance, it was pointed out that simple empirical lumped models cannot easily describe the complexity of the sediment cycle. Thus, the use of distributed models, capable of taking explicit account of spatial variability of the process, is required (Caviedes-Voullième et al., 2012; Bussi et al., 2014; Fernández-Pato et al., 2016; Herrero et al., 2017). Once they have been calibrated, even with short data sets, these models have the advantage of reproducing the spatial variability of water and erosional processes in the catchment, and can also be used to run simulations under different intra-basin (changes in land use and water uses) and extra-basin scenarios (climate change). The main drawback of distributed models is the input data requirement. GIS has emerged as a useful tool in developing data files required for this kind of distributed models.

Focusing on the distributed models, there are several ways of computing the temporal and spatial evolution of variables. In some cases, the set of equations has been solved by means of a Kinematic Wave model (Rai and Mathur, 2007). This methodology is simple and computationally efficient since it combines the mass and momentum equation into a single equation, but is unable to represent downstream effects. Another possibility is the choice of a Diffusion Wave based model (Ponce, 1986; Feng and Molz, 1997; Sarkar et al., 2008). However, it may lead to inefficient computation and important errors in case of simulating abrupt transient phenomena (Costabile et al., 2012). In this work, a 2D fully Dynamic Wave approach is the basis for a hydrological and erosion model to simulate the response of a quasi-perennial Mediterranean river basin (the Algars River Basin) during two storm events. The 2D Dynamic Wave model, running on triangular meshes, was previously developed and exhaustively tested in all kind of scenarios (Murillo and García-Navarro, 2010). Rainfall/runoff losses are estimated by means of an extended SCS (Soil Conservation Service) model as an additional mass source term for the $2 \mathrm{D}$ surface flow model. The sediment transport is simulated by means of a 2D extension of the Hillslope Erosion Model (HEM) (Harmon and Doe, 2001; Wigmosta et al., 2009) also coupled to the 2D surface flow model.

The large size of the selected study basin becomes an important issue, since the $\mathrm{CPU}$ time increases as the number of cells does. Furthermore, the complex topography of the catchment headwaters requires local refinement that increases the number of cells. 
Additionally, the problem of computational cost escalates in the calibration phase since the simulations should be repeated hundreds or thousands of times (Brath et al., 2004) for fitting the experimental data. To reduce the time consumption in the calibration phase, a conservation volume strategy has been implemented in this work using a Simplified Catchment Model (SCM) with a limited number of cells to provide a first guess of the infiltration and erosion parameters. Then, the set of values were refined for simulating the real catchment topography.

Currently, one of the main discussions around sediment models is the need for a reliable calibration and validation technique (Jetten et al., 1999), which is required in order to prove the model robustness and reliability. However, very few papers describe clear and scientifically acceptable calibration and validation procedures for sediment models, as it was already pointed out in Bussi et al. (2014). Therefore, the main goals of this work are: (i) The formulation and calibration of a robust and stable numerical scheme for $2 \mathrm{D}$ transient overland flow with rain, infiltration and erosion processes to simulate rainfall/runoff and erosion events in a Mediterranean watershed. The calibration of the model parameters is based on continuous series of water discharge and Suspended Sediment Concentration (SSC, obtained from turbidity records) data recorded in a real catchment. (ii) The introduction of the Simplified Catchment Model (SCM), which has proved to reduce the time required for calibrating the hydrological and morphological parameters of the model.

\section{Material and methods}

\subsection{Study area}

The River Algars is a mesoscale Mediterranean catchment located in the northeast of the Iberian Peninsula (Fig. 1). The river drains an area of $405 \mathrm{~km}^{2}$ upstream of the confluence with the River Matarraña $\left(1717 \mathrm{~km}^{2}\right)$, one of the tributaries of the River Ebro. The basin altitude ranges from 120 to 1296 m.a.s.l. The Algars catchment is strongly influenced by the Mediterranean climate. Mean temperature is $14^{\circ} \mathrm{C}$ in the lowermost part of the basin. The Algars basin is characterized by a rainfall-based flow regime with maximum values in spring and autumn and a minimum in summer (there is no snow retention), however it shows a high degree of seasonal and annual variability. Mean annual rainfall is $540 \mathrm{~mm}$, but it shows a slight elevation gradient with mean values around $400 \mathrm{~mm} \mathrm{y}^{-1}$ in the valley bottom, and higher than $650 \mathrm{~mm} \mathrm{y}^{-1}$ in the headwaters. The Mediterranean pluvial regime is extreme in this watershed. This fact is represented by the torrential character of the rainfall events, where a single event can represent half of the annual precipitation; or half an hour the $20 \%$, as in the event of 10 May 2002, registering $150 \mathrm{~mm}$ in 30 minutes. Mean daily discharges for the historic period recorded at the gauging station in Batea (1974-2013) was $0.6 \mathrm{~m}^{3} \mathrm{~s}^{-1}$, which represents a mean annual water yield of ca. $20 \mathrm{hm}^{3}$, although this value hides a high year-on-year variability, ranging from a minimum of $0.09 \mathrm{~m}^{3} \mathrm{~s}^{-1}(1978-79)$ to a maximum of 1.62 $\mathrm{m}^{3} \mathrm{~s}^{-1}$ (1976-77). The largest peak was recorded in autumn (November 2000), reaching $470 \mathrm{~m}^{3} \mathrm{~s}^{-1}$, a high value considering the aforementioned mean discharges. 


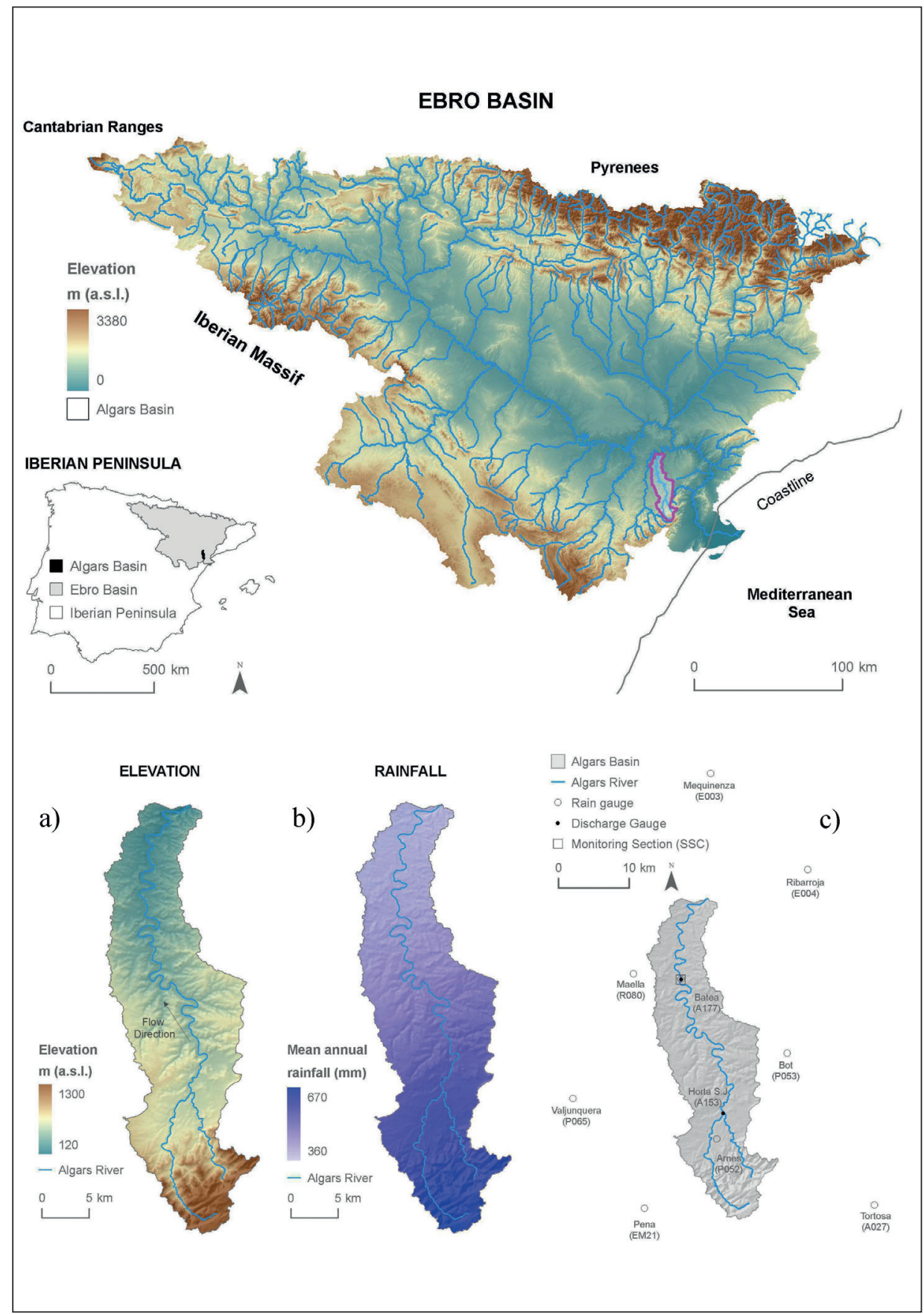

Figure 1. Location of the Algars basin in the Iberian Peninsula and the Ebro basin (upper panel) and detailed map of elevation (a), mean annual rainfall (b) and gauging stations (c) in the Algars basin. 
Geologically, two areas can be clearly differentiated in the Basin, the Puertos de Beceite in the headwaters, and the Ebro depression in the medium and lower reaches. In the headwater parts of the catchment the river flows through narrow gorges excavated on Jurassic and Cretaceous limestone and dolomites. In the medium reaches, the river enters into the Ebro depression, flowing through tertiary materials (mostly conglomerates, sandstones and marls, limestone and evaporites) shaping soft reliefs in which isolated hills are frequent as a result of differential erosion. At the valley bottom there is an identifiable alluvial zone, where bedrock often appears. The catchment materials suggest that groundwater outflows could exist at the Algars Basin.

Landscape in the headwaters has been slightly modified by humans, abounding coniferous forests, while in the lower reaches it has been heavily modified with farmland and crops, which coexist with sparse thicket shrub and small stands of conifers. The Algars watershed is not regulated, though water abstractions for irrigation and water supply for some villages are found in its main course.

\subsection{Events description: event 1 and event 2}

The particular characteristics of the events studied in this paper, both registered in March and April 2011, are here briefly summarized. Both events present a different nature and are equally useful for the purpose of this work. The flow and sediment dynamics of the Algars basin were recorded at several gauging stations as it is described in Figure 1c. The discharge and suspended sediment concentrations were much higher during the March flood. This flood registered the maximum discharge of the 2008-2011 period, attaining $43 \mathrm{~m}^{3} \mathrm{~s}^{-1}$ in Horta de Sant Joan and $39.5 \mathrm{~m}^{3} \mathrm{~s}^{-1}$ in Batea, discharges that represent a return period of 1.3 and 1.7 years, respectively. The April flood reached $14.8 \mathrm{~m}^{3} \mathrm{~s}^{-1}$ in Horta de Sant Joan (i.e. 1 year return period) and $8.2 \mathrm{~m}^{3} \mathrm{~s}^{-1}$ in Batea (i.e. 1.2 years). These values correspond to the annual ordinary flood occurring in the Algars basin. Mean SSC during the March event was $41 \mathrm{mg} \mathrm{l}^{-1}$, ranging from a minimum of $21 \mathrm{mg} \mathrm{l}^{-1}$ to a maximum of $290 \mathrm{mg} \mathrm{l}^{-1}$, while in the April flood, mean SSC was $15 \mathrm{mg} \mathrm{l}^{-1}$ with a minimum of $8 \mathrm{mg} \mathrm{l}^{-1}$ and a maximum of $50 \mathrm{mg} \mathrm{l}^{-1}$. The total suspended sediment load transported during the March event was $280 \mathrm{Mg}$, contrasting with the $23 \mathrm{Mg}$ registered in April. The event occurred in April 2011, which represents an annual ordinary flood, has been considered as the event 1 studied in this work. The March 2011 event was labeled as event 2 and represents the maximum flood episode in the 2008-2011 period. The cumulative rainfall of event 2 is twice the cumulative rainfall of event 1 (Fig. 2). Furthermore, the rainfall intensity was more concentrated within a temporal period for event 1 .

\subsection{Data collection}

\section{Flow discharge}

Water discharge was measured continuously in the upper part of the catchment at the Horta de Sant Joan Gauging Station and in the lower part of the catchment at the Batea Gauging Station (hereafter BGS), both of them operated by the Ebro Basin 
Water Authority (Confederación Hidrográfica del Ebro, hereafter CHE). Water stage was recorded every 15 minutes by an OTT Water Level and transformed into discharge using a height-discharge ( $h-Q)$ rating curve provided by CHE. Figure $2 \mathrm{a}, \mathrm{c}$ shows the observed hydrographs obtained at the two gauging stations for the two events.

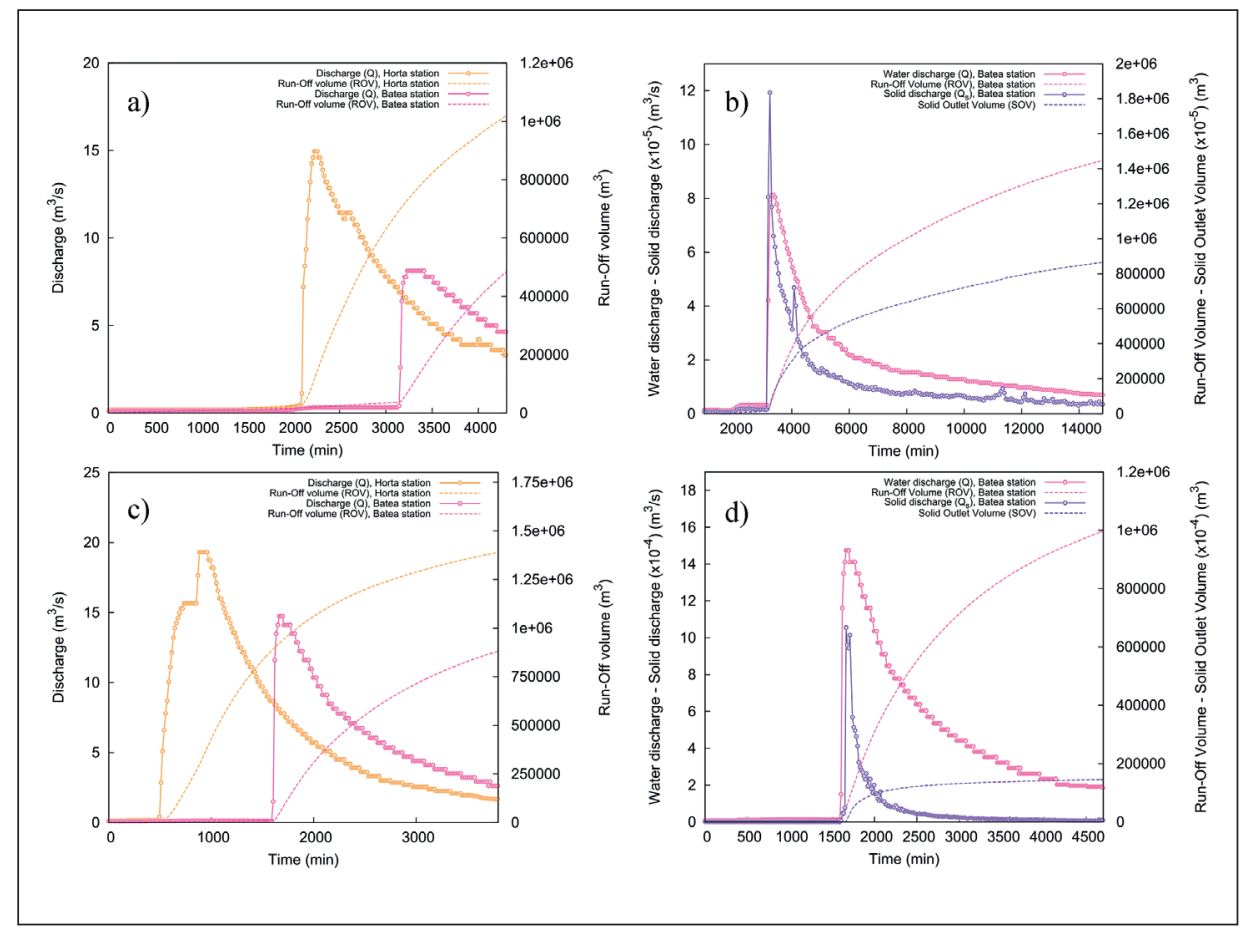

Figure 2. Observed data for Event $1(a, b)$ and Event $2(c, d)$ : hydrographs $(a, c)$ and sedigraph together with its corresponding hydrograph $(b, d)$.

\section{Rainfall}

Rainfall was also measured in the meteorological stations operated by CHE by means of tipping-bucket rain gauges. The information was collected at two stations located in the Algars basin. These stations were Arnes (P052) and Batea (A0177) (Fig. 1c). To complete the rainfall record, data was collected at six stations located in the surroundings of the Algars basin (Pena, EM21; Bot, P053; Valjunquera, P065; Maella, R080; Tortosa, A027; Mequinenza, E003; and Ribarroja, E004; Fig. 1c).

Point precipitation measurements obtained in the meteorological stations were converted into areal estimates by means of the Thiessen polygon technique (also called Voronoi tesselation). The use of this technique in the Algars catchment showed that only four stations had to be taken into account for the study case (Batea, Arnes, Bot and Maella). The resulting data collection for event 1 and 2 is displayed in Figures 3 and 4, respectively. 
Juez et al.

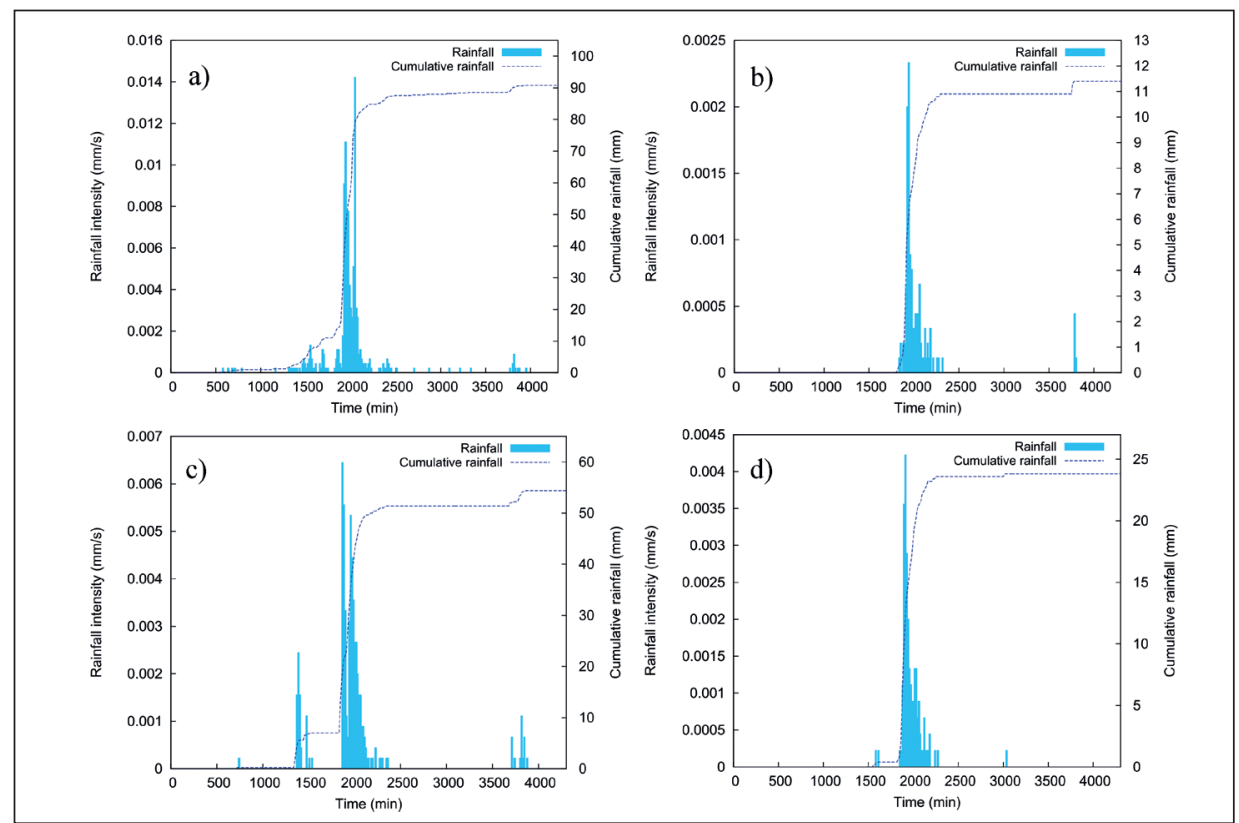

Figure 3. Event 1. Measured hyetographs for (a) Arnes station, (b) Batea station, (c) Bot station and (d) Maella station.

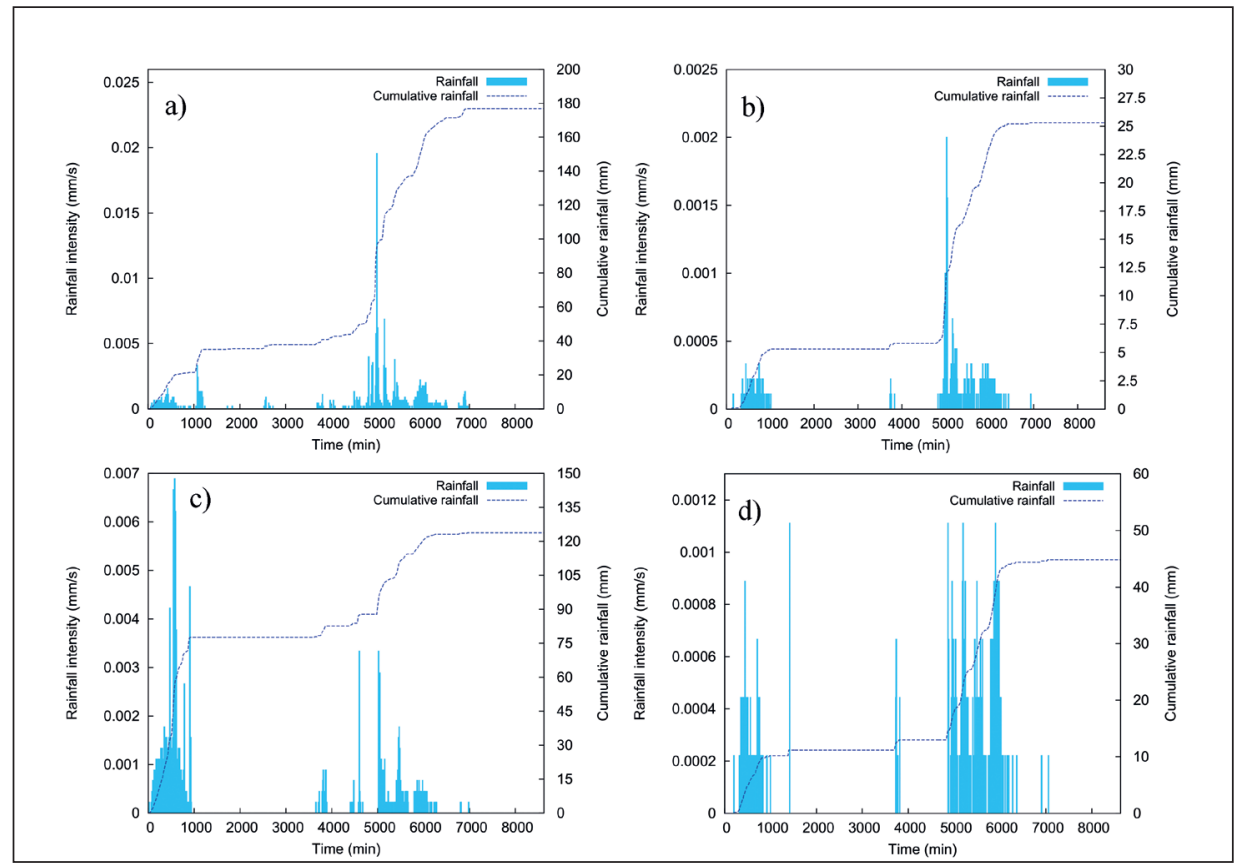

Figure 4. Event 2. Measured hyetographs for (a) Arnes station, (b) Batea station, (c) Bot station and (d) Maella station. 


\section{Turbidity}

Turbidity series were obtained in the lower part of the catchment at BGS (A177; Fig. 1c). Turbidity (a proxy of suspended sediment concentration) was measured every minute by means of an optical turbidity probe of McVann Analite NEP9530 (range 0-1000 NTU) and 15 minutes averages were recorded into a linked Campbell CR-800 data-logger.

More than 150 water and suspended sediment samples taken between 2008 and 2012 were used to convert the turbidity records into SSC. Samples were taken under a wide range of flow conditions, from base flows $\left(0.01 \mathrm{~m}^{3} \mathrm{~s}^{-1}\right)$ to flood flows (average discharge of $28 \mathrm{~m}^{3} \mathrm{~s}^{-1}$ ) accounting for $98 \%$ of the time of the flow duration curve of the monitoring period. Water samples were obtained by means of a cable-suspended depthintegrating US DH-56 sampler (for more details on sampling procedures see Tena et al., 2011). Water samples were taken close to the turbidity probe to guarantee a good relation between turbidity and SSC. Water samples were carried to the laboratory and filtered using $1.2 \mu \mathrm{m}$ cellulose and glass microfiber filters. Filters were dried and weighted to determine the SSC.

A rating curve between pair values of turbidity (in NTU) and SSC (in $\mathrm{mg} \mathrm{l}^{-1}$ ) was established by the authors thanks to the field data at BGS. The relationship is statistically significant. The rating curve obtained at BGS was:

$$
S S C_{B G S}=0.99 N T U_{B G S}-6 \text { with } \mathrm{N}=156, \mathrm{r}=0.97, \mathrm{p}<0.001
$$

The suspended sediment load transported during the study period was calculated on an hourly base from SSC and discharge measurements. The resulting sedigraph together with its corresponding hydrograph is displayed in Figure 2b, d.

\section{GIS based data}

The Digital Elevation Model (DEM) of the Algars Basin was obtained with 50x50 m grid resolution from the National Geographic Institute of Spain (IGN).

\section{Land Use and Roughness}

Land use was estimated from the CORINE land cover database (EC, 1994). In this handbook the land occupation is classified in the 3-level CORINE nomenclature, which is then ramified in 44 classes.

Once the land use was defined, it was converted into Manning's roughness (Manning, 1895) by means of values previously used in the literature (Chow, 1959; Aldridge and Garret, 1973) (see Fig. 5a, b).

\section{Permeability}

The permeability was obtained from the lithostratigraphic map of Spain (at 1: 50,000 ), defined by the Spanish Geological Survey (IGME) with hydrogeological criteria. Qualitative categories of permeability bedrock, associated with different lithological units, were classified into five types of permeability: Very high (MA), High 
(H), Medium (M), Low (L), Very Low (MB) and seven groups of lithologies: Carbonated (C), Detrital (D), Detrital Quaternary (Q), Volcanic (V), Metadetrital (M), Igneous (I) and Evaporite (E). Each qualitative category corresponds to a range of permeability values. The reclassification was carried out using values found in the literature (Davis, 1969; Freeze and Cherry, 1979; Brace, 1980). Additionally, the permeability map information (Fig. 5c) has been turned into a SCS map with two different values (Fig. 5d). More details about the SCS values are provided in section 4.2.

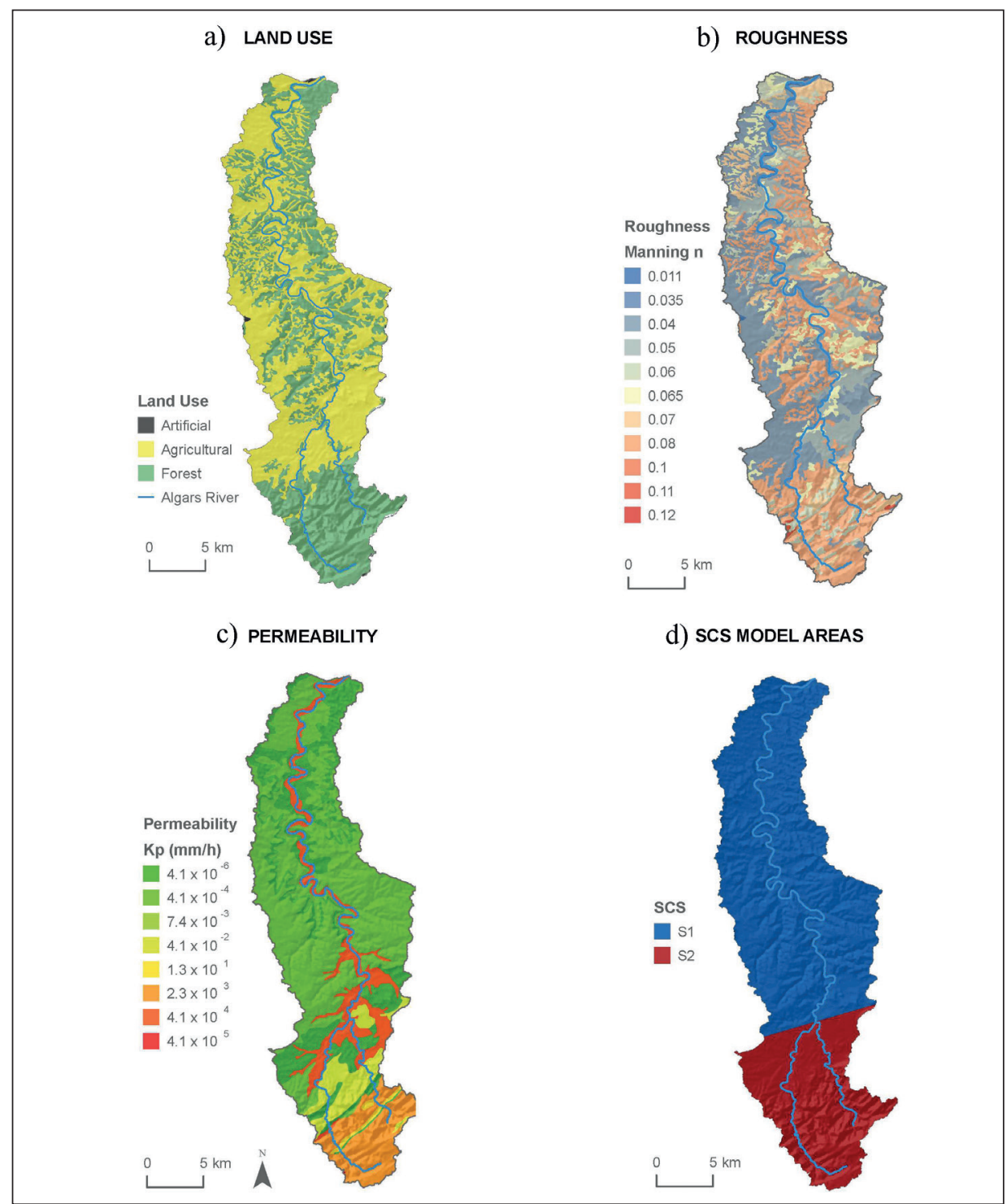

Figure 5. Land uses (a), Manning's roughness parameter (b), permeability (c) and SCS regions (d) in Algars basin. 


\section{Model description}

\subsection{Surface flow model}

The surface flow is formulated as a Dynamic Wave model (Murillo and GarcíaNavarro, 2010), which it is expressed as:

$$
\begin{aligned}
& \frac{\partial h}{\partial t}+\frac{\partial q_{x}}{\partial x}+\frac{\partial q_{y}}{\partial y}=R \\
& \frac{\partial q_{x}}{\partial t}+\frac{\partial}{\partial x}\left(\frac{q_{x}^{2}}{h}+\frac{1}{2} g h^{2}\right)+\frac{\partial}{\partial y}\left(\frac{q_{x} q_{y}}{h}\right)=g h\left(S_{0 x}-S_{f x}\right) \\
& \frac{\partial q_{y}}{\partial t}+\frac{\partial}{\partial x}\left(\frac{q_{x} q_{y}}{h}\right)+\frac{\partial}{\partial y}\left(\frac{q_{y}^{2}}{h}+\frac{1}{2} g h^{2}\right)=g h\left(S_{0 x}-S_{f x}\right)
\end{aligned}
$$

This set of equations is re-written in a compact form, as follows:

$$
\frac{\partial U}{\partial t}+\frac{\partial F(U)}{\partial x}+\frac{\partial G(U)}{\partial y}=S+H+M
$$

where

$$
U=\left(h, q_{x}, q_{y}\right)^{T}
$$

are the conserved variables, being $h$ the water depth (m) and $q_{x}=h u$ and $q_{y}=h v$ the unit discharges $\left(\mathrm{m}^{2} \mathrm{~s}^{-1}\right)$, with $u$ and $v\left(\mathrm{~m} \mathrm{~s}^{-1}\right)$ the depth averaged components of the velocity vector, $u$, along the $x$ and $y$ coordinates, respectively. The convective terms expressed in terms of the conserved variables are given by:

$$
F=\left(q_{x}, \frac{q_{x}^{2}}{h}+\frac{1}{2} g h^{2}, \frac{q_{x} q_{y}}{h}\right)^{T}, \quad G=\left(q_{y}, \frac{q_{x} q_{y}}{h}, \frac{q_{y}^{2}}{h}+\frac{1}{2} g h^{2}\right)^{T}
$$

where $g$ represents the gravity acceleration. The source terms of the system are split in three kind of terms. The term $\boldsymbol{S}$ corresponds to friction and is written as:

$$
S=\left(0,-g h S_{f x},-g h S_{f y}\right)^{T}
$$


The terms $S_{f x}, S_{f y}$ are the friction slopes in the $\mathrm{x}$ and y direction respectively, written in terms of the Manning's roughness coefficient $n\left(\mathrm{~s} \mathrm{~m}^{-1 / 3}\right)$ :

$$
S_{f x}=\frac{n^{2} u \sqrt{u^{2}+v^{2}}}{h^{4 / 3}} \quad S_{f y}=\frac{n^{2} v \sqrt{u^{2}+v^{2}}}{h^{4 / 3}}
$$

The term $\boldsymbol{H}$ corresponds to the bed slope and it is defined as:

$$
H=\left(0, g h S_{0 x}, g h S_{0 y}\right)^{T}=\left(0, g h \frac{\partial z}{\partial x},-g h \frac{\partial z}{\partial y}\right)^{T}
$$

Finally, the term $\boldsymbol{M}$ represents the mass sources/sinks due to rainfall/infiltration:

$$
M=\left(R_{e}-f, 0,0\right)^{T}
$$

being $R_{e}\left(\mathrm{~m} \mathrm{~s}^{-1}\right)$ and $f\left(\mathrm{~m} \mathrm{~s}^{-1}\right)$ the effective rainfall and the infiltration rate, respectively.

System (5) is time dependent, non linear, and contains source terms. It is possible to define a Jacobian matrix, $\boldsymbol{J}_{n}$, of the flux normal to an outward direction given by the unit vector $\boldsymbol{n}, \boldsymbol{E n}=\boldsymbol{F} n_{x}+\boldsymbol{G} n_{y}$, defined as in Murillo and García-Navarro (2010):

$$
J_{n}=\frac{\partial E n}{\partial U}=\frac{\partial F}{\partial U} n_{x}+\frac{\partial G}{\partial U} n_{y}
$$

\subsection{SCS-CN runoff model}

In the Soil Conservation Service-Curve Number (SCS-CN) model, the main parameter is the Curve Number $(\mathrm{CN})$, used to reduce the total precipitation to effective precipitation, by taking into account the losses (evaporation, absorption, transpiration and surface storage). In general terms, the higher the $\mathrm{CN}$ value is, the higher the potential runoff. Effective rainfall, $R_{e}(\mathrm{~mm})$ is defined as in USDA (1986):

$$
R_{e}= \begin{cases}\frac{\left(R V-I_{a}\right)^{2}}{R V-I_{a}+S} & \text { if } R V>I_{a} \\ 0 & \text { if } R V \leq I_{a}\end{cases}
$$

where $R V$ is the Rain Volume $(\mathrm{mm}), I_{a}$, the Initial abstraction (infiltration depth before runoff) ( $\mathrm{mm}$ ) and $S$, the Potential of maximum retention $(\mathrm{mm})$, estimated by:

$$
S=\frac{25400}{C N}-254
$$

The initial abstraction is estimated as a fraction of $S$ :

$$
I_{a}=\alpha S
$$


The value of $\alpha$ has been traditionally considered equal to 0.2 , (USDA, 1986). However, recent studies suggest that this value can vary depending on the soil properties (Caviedes-Voullième et al., 2012). Accordingly, in this work different values of $\alpha$ have been selected for each SCS region (see Fig. 5d) in order to perform the numerical simulations. It is worth noting that the value of $\alpha$ is spatially constant within each SCS region.

Despite the simplicity of the SCS-CN method (as e.g. it cannot model exfiltration and underground water flow) the potential of it is amplified when it is combined with a fully $2 \mathrm{D}$ overland-flow model, since the values for water depth and velocities are local (i.e. different from cell to cell). The SCS-CN method is thus applied cell by cell (and not to the entire catchment, as lumped methods do) so that the runoff is calculated for each cell in every time step, using the rain volume value since the beginning of the event. A SCS region map (Fig. 5d) based on the catchment permeability values has been developed in order to get a more realistic computation of the infiltration. Despite of the spatially explicit nature of the calibrated SCS parameters, only two values of $\mathrm{CN}$ have been considered. The Algars catchment presents two very different regions with homogeneous characteristics in terms of land use, roughness and permeability: the northern part of the catchment is mainly devoted to agricultural purposes, whereas the southern part is mainly forested (see Fig. 5).

\subsection{Hillslope Erosion Model}

For the evaluation of the sediment transport phenomenon in the watershed the Hillslope Erosion Model (HEM) is considered (Shyrley and Lane, 1978). This model is simple and robust and it has been used and tested in previous works (Lane et al., 1995; Harmon and Doe, 2001; Wigmosta et al., 2009). It is based on a sediment continuity equation together with a combination of several parameters that are related with the canopy cover, the catchment slopes and the soil erodibility. Originally, it was derived as a 1D model. An extension for 2D flows is written as follows:

$$
\frac{\partial(h \phi)}{\partial t}+\frac{\partial\left(q_{x} \phi\right)}{\partial x}+\frac{\partial\left(q_{y} \phi\right)}{\partial y}=E_{i}+E_{r}
$$

with

$$
\begin{aligned}
& E_{i}=K_{i} R_{e} \\
& E_{r}=K_{r}\left(\frac{n B}{\sqrt{|S|}}-\phi\right)|q|, \quad S=\left(S_{o, x}, S_{o, y}\right), \quad q=\left(q_{x}, q_{y}\right)
\end{aligned}
$$

Being $\varnothing$ the sediment concentration in $\mathrm{kg} \mathrm{m}^{-3}, E_{i}$ the interrill erosion rate per unit area in $\mathrm{kg} \mathrm{s}^{-1} \mathrm{~m}^{-2}$ and $E_{r}$ the net rill erosion or deposition rate per unit area in $\mathrm{kg} \mathrm{s}^{-1} \mathrm{~m}^{-2}$. 
$K_{r}$ is the rill erosion coefficient in $\mathrm{m}^{-1}, K_{i}$ is the interrill erosion coefficient in $\mathrm{kg} \mathrm{m}^{-3}$ and $B$ is the transport capacity coefficient in $\mathrm{kg} \mathrm{s}^{-1} \mathrm{~m}^{-8 / 3}$. All these parameters are expected to vary locally within the catchment since they depend on the land cover, soil type, etc. They thus require a calibration process that has been addressed in the following sections by means of a non-trivial, heuristic procedure.

Due to the fact that the sediment erosion on this catchment does not provoke a net change in the topography, no morphological changes are considered in this work following Lane et al., 1995.

\subsection{Numerical scheme}

A finite volume scheme is applied to system (5) and equation (16). They are both integrated in cell volumes $\Omega_{\mathrm{i}}$ as follows:

$$
\begin{aligned}
& \frac{\partial}{\partial t} \int_{\Omega \mathrm{i}} U d \Omega \mathrm{i}+\oint_{\partial \Omega \mathrm{i}} E n d l=\int_{\Omega \mathrm{i}}(S+H+M) d \Omega \mathrm{i} \\
& \frac{\partial}{\partial t} \int_{\Omega \mathrm{i}} h \phi d \Omega \mathrm{i}+\oint_{\partial \Omega \mathrm{i}} E \phi n d l=\int_{\Omega \mathrm{i}}\left(E_{i}+E_{r}\right) d \Omega \mathrm{i}
\end{aligned}
$$

$\partial \Omega i$ is the surface corresponding to the cell volume $\Omega i$ and $\mathbf{n}=\left(\mathrm{n}_{\mathrm{x}}, \mathrm{n}_{\mathrm{y}}\right)$ the vector that flows out the volume $\Omega i$. The domain forms an unstructured mesh and a piecewise representation of the variables is assumed. The fluxes and source terms for both, water and sediment, are calculated using a Roe approximate Riemann solver (Murillo and García-Navarro, 2010). Hence, the conserved variables at every cell are updated in time by means of a splitting technique for the water (Murillo and García-Navarro, 2010) and a flux scheme for the sediment transport (Murillo and García-Navarro, 2011):

$$
\begin{aligned}
& U_{i}^{n+1}=U_{i}^{n}-\sum_{k=1}^{N E=3} \partial M_{i, k}^{-} \frac{\Delta t l_{k}}{A_{i}} \\
& (h \phi)_{i}^{n+1}=(h \phi)_{i}^{n}-\sum_{k=1}^{N E=3}(q \phi n)_{i, k}^{-} \frac{\Delta t l_{k}}{A_{i}}+\left(E_{i}+E_{r}\right) \Delta t
\end{aligned}
$$

The superscript $n$ represents the time level $\left(\mathrm{t}^{\mathrm{n}+1}=\mathrm{t}^{\mathrm{n}}+\Delta \mathrm{t}\right)$, the subscript $i$ is the cell position, $A_{i}$ is the cell area, $N E$ is the number of edges, $l_{k}$ is the length of the cell edge and $\Delta t$ is the computational time step. The water fluxes, $\partial M_{i, k}^{-}$are evaluated at the intercells, $k$, and the superindex ${ }^{-}$becomes necessary for considering only the incoming fluxes. The solid fluxes $(\boldsymbol{q} \phi \boldsymbol{n})_{i, k}^{-}$, i.e. the sediment particles convectively transported, also denote the incoming solid fluxes to the cell edges. 
For ensuring the stability of the numerical scheme the computational time step must be small enough for avoiding interactions between neighboring waves (Leveque, 2002). Henceforth, a dynamic time step choice can be formulated as follows:

$$
\Delta t=C F L \frac{\min (X)}{\max \left|\lambda^{m}\right|} \text { with } C F L \leq 0.5
$$

where the Courant-Friedrich-Lewy (CFL) condition is the standard for the stability control of explicit schemes, $X$ is a relevant distance between neighboring cell centers (Murillo and García-Navarro, 2010; Juez et al., 2014) and $\lambda^{m}$ the hydrodynamic celerities. Since the sediment transport is not intense enough for causing changes in the topography, no extra restriction is required for stability. Therefore, the hydrodynamic variables are solved first and then, they are used for computing the sediment transport.

\section{Results and discussion}

\subsection{Simplified catchment modeling (SCM)}

The empirical infiltration (SCS) and the erosion (HEM) models used in this work require the calibration of a set of parameters. In both cases, this is carried out following trial and error steps to reproduce the outlet hydrograph and sedigraph from the inlet rainfall data. In order to consider all the topography details of the catchment, the terrain has been modeled by using a triangular unstructured mesh (Fig. 6) which contains 158,000 cells and is locally refined in the vicinity of the alluvial channel. The maximum cell size is $600 \mathrm{~m}^{2}$ and the minimum is $150 \mathrm{~m}^{2}$. With such a large number of cells, the calibration process may take a long time, as the simulations are repeated until the best fit for infiltration/erosion parameters are found. In the present case, each simulation takes approximately $24 \mathrm{~h}$ using an Intel Core i7-4770@3.40 GHz CPU with 32GB of RAM.

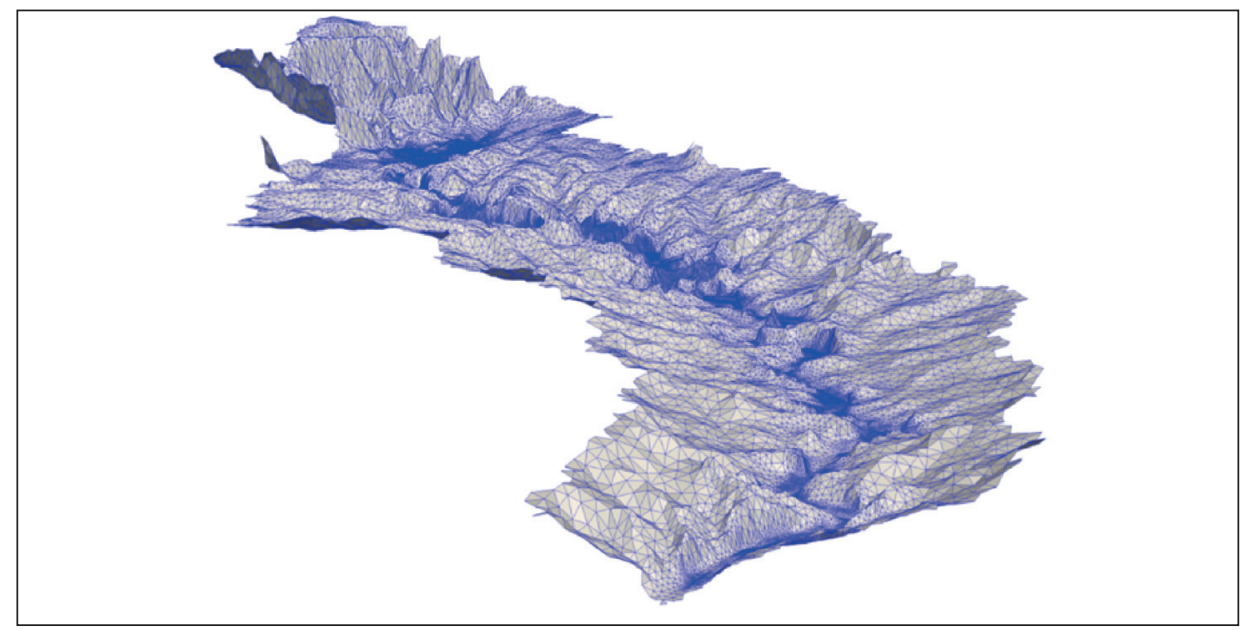

Figure 6.3D mesh representation of the computational mesh (158000 cells). 
In order to minimize the cost of the calibration process by reducing the number of steps, a simplified catchment model (SCM), based on conservation of volume, is proposed in this section. The only goal of this model is to provide a first set of SCS and HEM parameters as a starting point for the calibration in the real catchment. It thus represents a tool to obtain a first approach of the infiltration/erosion parameters and does not proceed blindly when simulating the real basin, hence saving computational efforts. It is noted that the first set of SCS parameters considered for the toy catchment may lead to unsatisfying results (i.e. bad fit). If this occurs, a new set of parameters is chosen and the calibration in the simplified catchment is performed newly. The limited number of cells involved in the computation at this stage allows running new calibrations without any time constraint. A sketch with the physical processes occurring in the catchment as well as the flow chart of the computing/calibrating algorithms is displayed in Fig. 7.

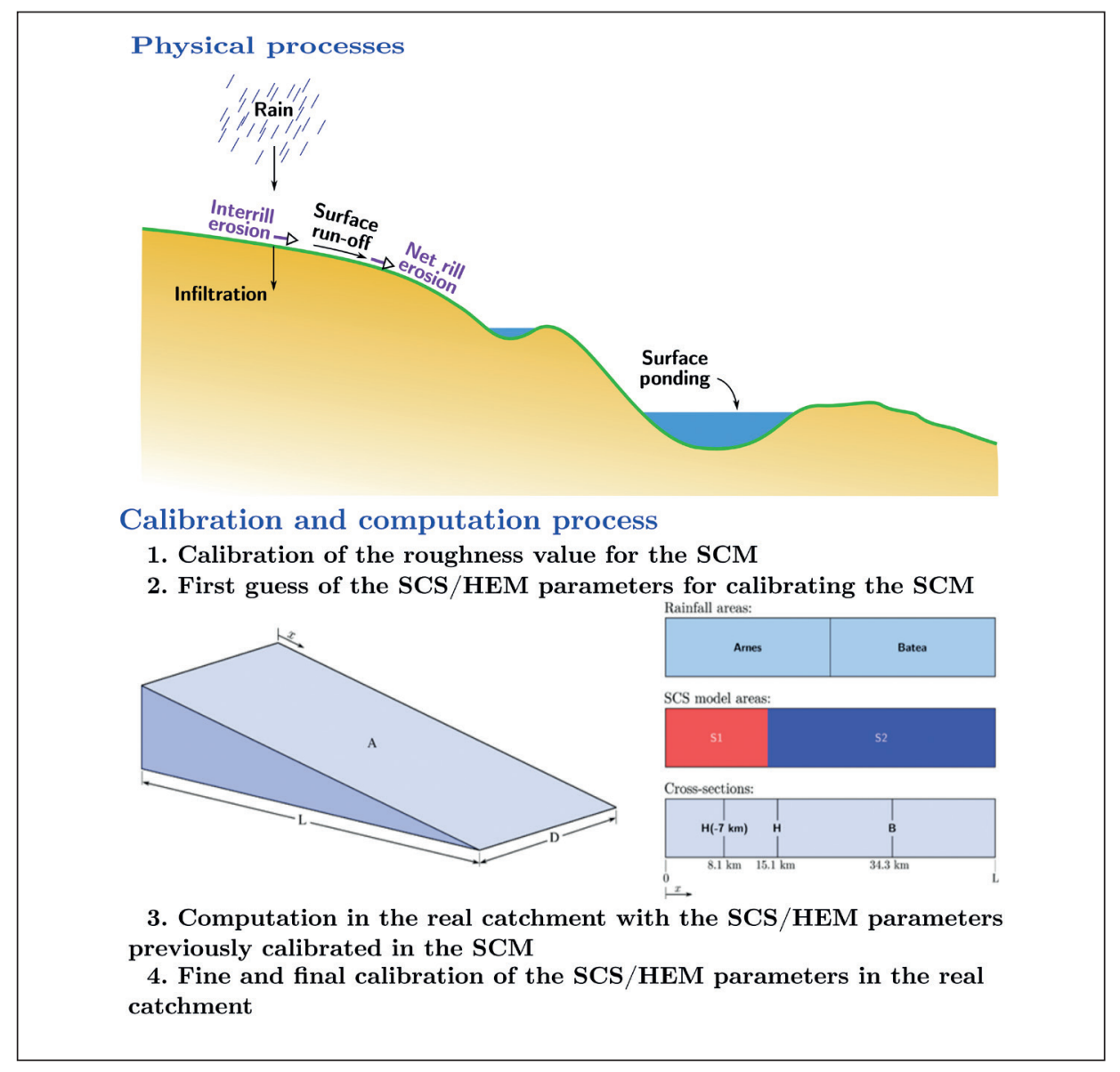

Figure 7. Physical processes occurring in the catchment (top) and flow chart of the algorithms for computing/calibrating such processes (bottom). The Simplified Catchment Model (SCM) displays: the slope geometry (bottom-left) and the rainfall areas, SCS areas and cross-sections (bottom-right). 
In the SCM, the catchment topography is reduced to a single slope plane (Fig. 7) with the same area A of the real catchment $\left(419 \mathrm{~km}^{2}\right)$. The length of the plane, $L$, is assumed to be approximately the same as the main channel $(46 \mathrm{~km})$, so the plane width, $\mathrm{D}$, becomes $\mathrm{D}=\mathrm{A} / \mathrm{L}=9.1 \mathrm{~km}$. The plane slope is assumed as the mean value of the alluvial channel of the real catchment $(0.026)$. The resulting domain is discretized in only 200 cells, with a maximum cell size of $200,000 \mathrm{~m}^{2}$ and a minimum of $66,000 \mathrm{~m}^{2}$. The computational cost for each simulation in the simplified model is approximately 30 seconds, which implies an important save of computational effort when comparing with the simulation of the real topography. Rainfall setup for this model accounts only for the two most relevant stations (Arnes and Batea) (Fig. 7).

In order to find the adequate Manning's roughness value for this simplified model a simple procedure is followed. First, a simulation is performed using the real catchment topography under impervious conditions, computing the outlet hydrographs in both Horta de Sant Joan and Batea stations. Then, several simulations are carried out in the SCM, also assuming impervious soil, varying the roughness coefficient until the outlet hydrographs computed at cross-sections $\mathrm{H}$ and $\mathrm{B}$ (Fig. 8) fit the ones obtained in the real catchment at Horta de Sant Joan and Batea. In Figure 8, a much better fitting is obtained when placing the $\mathrm{H}$ gauge $7 \mathrm{~km}$ upstream $(\mathrm{H}(-7 \mathrm{~km})$ in Fig. 7). The reason for this behaviour is the change on the slope trend near this station in the real catchment topography. This fact cannot be considered by a single slope based simplified model and that is why the gauge has been repositioned.

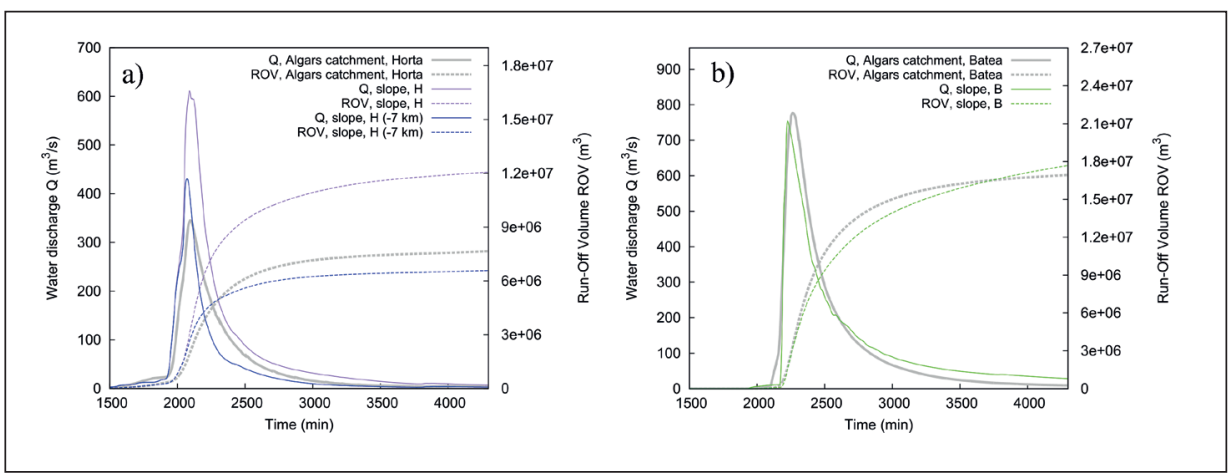

Figure 8. Impervious hydrograph fitting at Horta de Sant Joan (a) and Batea (b) for the search for the Manning's roughness coefficient of the SCM.

The roughness fitting leads to a SCM Manning's coefficient of $0.0038 \mathrm{~s} \mathrm{~m}^{-1 / 3}$, which is far from the real roughness values of the catchment. The reason for this difference is that the simplicity of the slope cannot consider all the real catchment topography details, as lateral slopes, depressions or the sinuosity of the main channel. Hence, all these features are "included" in the roughness value obtained for the SCM.

Once the SCM is configured, a set of simulations is done in order to fit the observed hydrographs/sedigraphs data by changing the input parameters of SCS/HEM models. The set of parameters that provides the best fit will be used as input for these models in the simulation 
of the real catchment. Note that the simulation of the real catchment can never be replaced by the SCM. As stated before, this simplified model represents just an approaching tool for a fast estimation of the SCS/HEM parameters or, at least, their order of magnitude. These parameters need to be properly re-calibrated using the real catchment topography.

\subsection{Calibration of the SCS model parameters}

A first calibration of the SCS parameters is performed in the SCM to fit the observed hydrographs, paying special attention to the outlet water volume. Two different regions (S1 and S2) are considered for the SCS model setup (Fig. 7), representing approximately the same areas as the ones used for the real catchment. The resulting hydrographs and the comparison with the observed data are shown in Figure $9(\mathrm{a}, \mathrm{b})$. Two sets of parameters have been selected: $S C S 01=\{\mathrm{CN}(\mathrm{S} 1)=75, \alpha(\mathrm{S} 1)=0.57, \mathrm{CN}(\mathrm{S} 2)=75, \alpha(\mathrm{S} 2)=0.57\}$ and $S C S 02=\{\mathrm{CN}(\mathrm{S} 1)=72$, $\alpha(\mathrm{S} 1)=0.57, \mathrm{CN}(\mathrm{S} 2)=75, \alpha(\mathrm{S} 2)=0.57\}$. Figure 9a shows that a single infiltration region is not enough to reproduce both observed hydrographs. By setting the same SCS parameters for both regions, even if the correct runoff volume is achieved for the first hydrograph (Horta de Sant Joan station), the second one (Batea station) is overestimated.

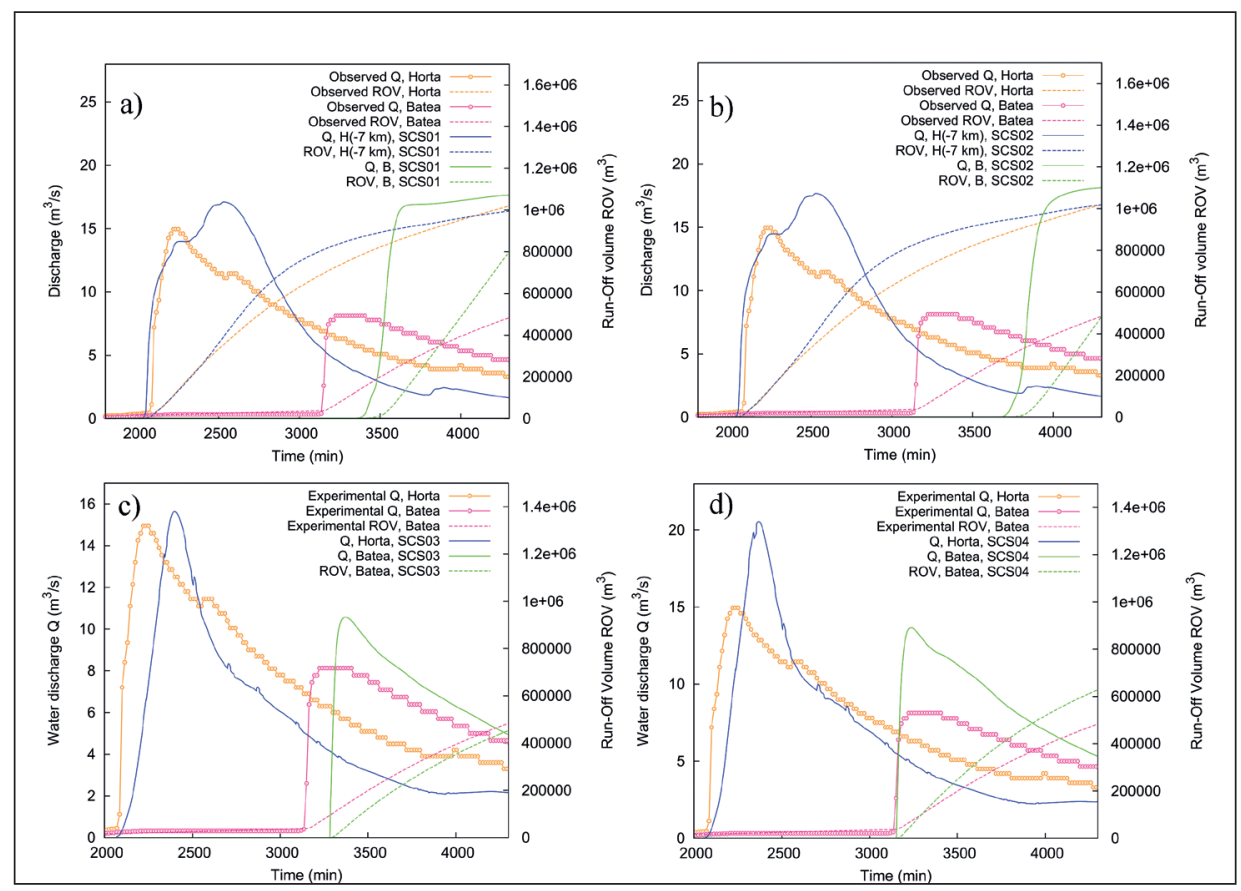

Figure 9. Calibration of the SCS model parameters for the event 1. (a,b) SCS parameters first calibration (SCM), (c,d) SCS parameters second calibration (real catchment).

With these sets of parameters as starting point, the next step is transferring to the real catchment the SCS parameters found by means of the SCM and perform a re-calibration, if needed, by fitting again the observed hydrograph. The results are shown in Figure 
9c,d. Two sets of parameters have been chosen: $S C S 03=\{\mathrm{CN}(\mathrm{S} 1)=73, \alpha(\mathrm{S} 1)=0.57$, $\mathrm{CN}(\mathrm{S} 2)=65, \quad \alpha(\mathrm{S} 2)=0.57\} \quad$ and $S C S 04=\{\mathrm{CN}(\mathrm{S} 1)=74, \quad \alpha(\mathrm{S} 1)=0.57, \quad \mathrm{CN}(\mathrm{S} 2)=66$, $\alpha(\mathrm{S} 2)=0.57\}$. Using the approach described, only two fit types were possible depending on the target variable: the cumulative outlet runoff (SCS03 set, see Figure 9c) or the time of peak discharge (SCS04 set, see Figure 9d). In this work, the adjustment of the runoff volume is preferable in order to give priority to the fitting of this observed quantity.

By following the same procedure, the SCS parameters for the second event are found: $S C S O 5=\{\mathrm{CN}(\mathrm{S} 1)=90, \alpha(\mathrm{S} 1)=0.37, \mathrm{CN}(\mathrm{S} 2)=71, \alpha(\mathrm{S} 2)=0.57\}$ and $S C S 06=\{\mathrm{CN}(\mathrm{S} 1)=91$, $\alpha(\mathrm{S} 1)=0.37, \mathrm{CN}(\mathrm{S} 2)=72, \alpha(\mathrm{S} 2)=0.57\}$. This choice of parameters is guided by the fact that the soil moisture was higher during the second event (Event 1). Figure 10 shows the resulting calibrations of the SCS model. As in the previous event, the first parameter set (SCS05) provides an outlet hydrograph that fits the outlet runoff volume at Batea station. The second set (SCS06) allows getting a better approximation of the discharge peak starting time. However, the peak value and the outlet runoff volume slightly differ with respect to the observed data. The numerical outcomes in this event face more difficulties than in the previous event for fitting the observed data. This fact is caused by the nature of the event modeled (the one with the maximum discharge within a four years period), which may have triggered different phenomena in the catchment, not considered in the present model, such as local sediment deposition altering the river channel morphology.

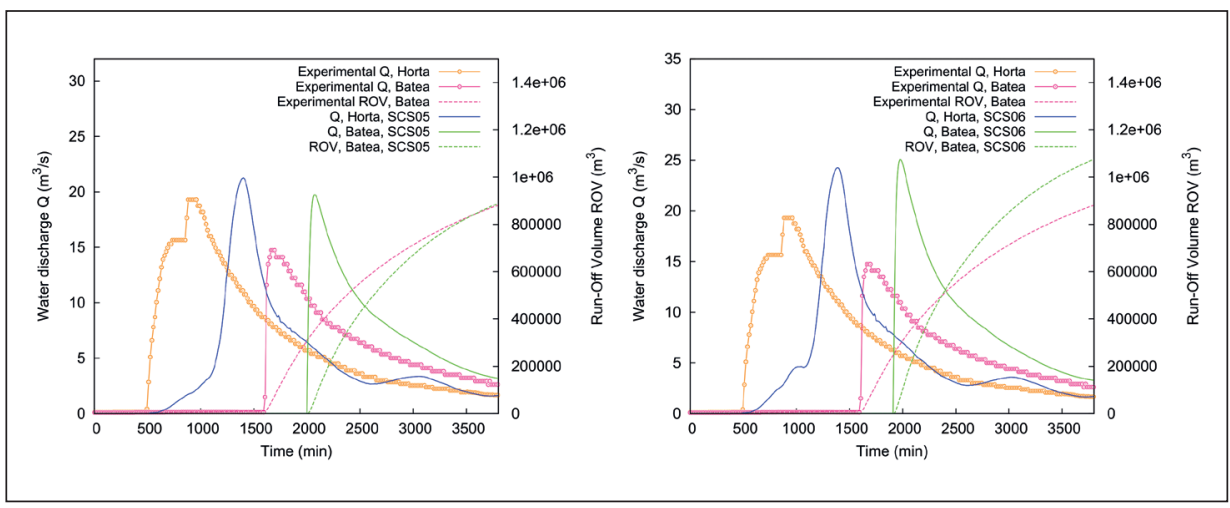

Figure 10. Calibration of the SCS model parameters for the event 2 (real catchment).

\subsection{Calibration of the HEM parameters}

The second stage of the full process is the fitting to the observed sedigraph. The same procedure as followed for the SCS model is considered. First, the HEM parameters are provisionally fit by means of the SCM, leading to two possible parameter sets: $H E M 01=\left\{K_{i}=0.005 \mathrm{~kg} \mathrm{~m}^{-3}, K_{r}=0.02 \mathrm{~m}^{-1}, B=0.001 \mathrm{~kg} \mathrm{~m}^{-8 / 3} \mathrm{~s}^{-1}\right\}$ and HEMO2 $=\left\{K_{i}=0.0037 \mathrm{~kg} \mathrm{~m}^{-3}, K_{r}=0.02 \mathrm{~m}^{-1}, B=0.001 \mathrm{~kg} \mathrm{~m}^{-8 / 3} \mathrm{~s}^{-1}\right\}$. Figure 11a shows the hydrograph corresponding to these sets of parameters and the comparison with the observed data. As in the SCS calibration, the set of parameters that adjusts the solid outlet volume (SOV) is taken as the best fit (HEM02). 


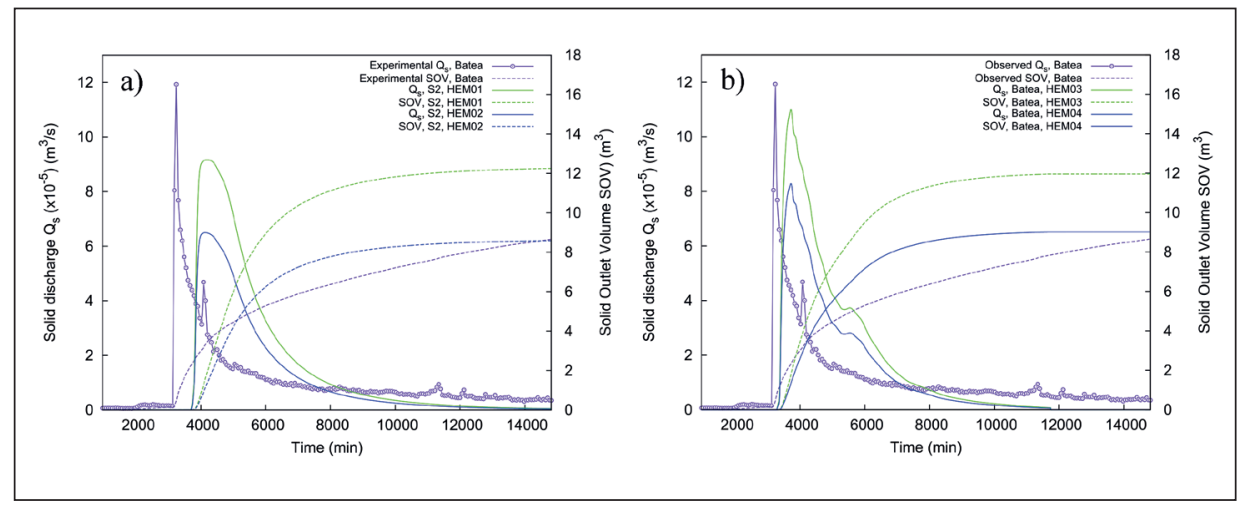

Figure 11. Calibration of the HEM parameters for the event 1. (a) HEM parameters first calibration (SCM), (b) HEM parameters second calibration (real catchment).

After considering the HEM02 set of parameters as starting values, a second fit is performed in the real catchment. Another two possible adjustments are obtained, depending on the interest of calibrating the solid discharge peak (HEM03 set), corresponding to the green line in Figure $11 \mathrm{~b}$, or the solid outlet volume (HEM04 set), corresponding to the blue line in Figure 11b. The obtained HEM parameters for these two adjustments are detailed as follows: $H E M 03=\left\{K_{i}=0.0007 \mathrm{~kg} \mathrm{~m}^{-3}, K_{r}=0.004 \mathrm{~m}^{-1}\right.$, $\left.B=0.001 \mathrm{~kg} \mathrm{~m}^{-8 / 3} \mathrm{~s}^{-1}\right\}$ and HEMO4 $=\left\{K_{i}=0.0007 \mathrm{~kg} \mathrm{~m}^{-3}, K_{r}=0.003 \mathrm{~m}^{-1}, B=0.001 \mathrm{~kg} \mathrm{~m}^{-8 / 3} \mathrm{~s}^{-1}\right\}$.

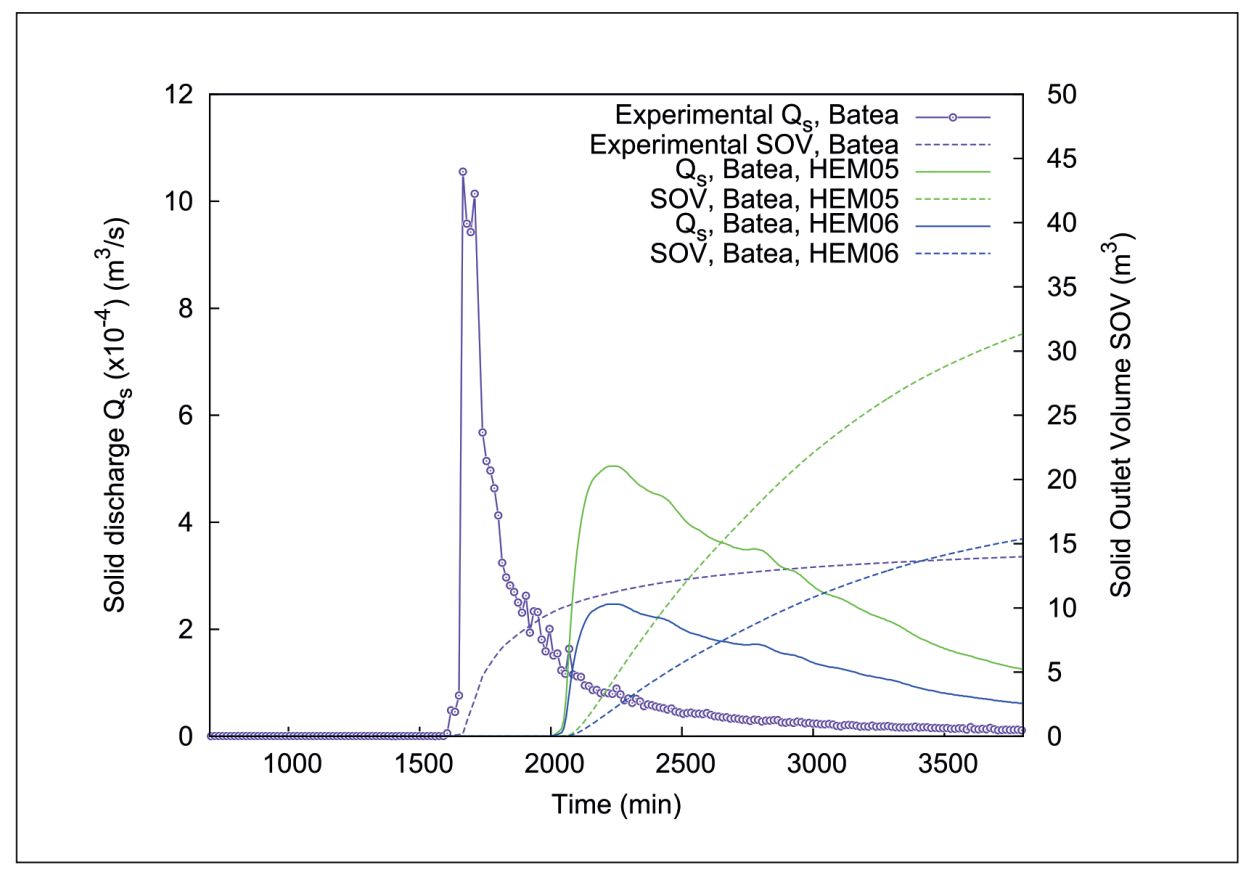

Figure 12. Calibration of the HEM parameters for the event 2 (real catchment). 
For the event 2 (Fig. 12) the corresponding HEM parameter sets are HEM05 $=\left\{K_{i}=0.00008 \mathrm{~kg} \mathrm{~m}^{-3}, K_{r}=0.0017 \mathrm{~m}^{-1}, B=0.003 \mathrm{~kg} \mathrm{~m}^{-8 / 3} \mathrm{~s}^{-1}\right\}$ for fitting the solid outlet volume and HEMO6 $=\left\{K_{i}=0.0001 \mathrm{~kg} \mathrm{~m}^{-3}, K_{r}=0.0035 \mathrm{~m}^{-1}, B=0.003 \mathrm{~kg} \mathrm{~m}^{-8 / 3} \mathrm{~s}^{-1}\right\}$ for a better adjustment of the solid discharge peak.

In general terms, an adequate agreement between numerical and observed data is observed. Regarding the event 1 , the relative error (calculated as $\left(\mathrm{X}_{\text {computed }}-\mathrm{X}_{\text {measured }}\right)$ / $\mathrm{X}_{\text {measured }}$, being $\mathrm{X}$ the target variable) for the outlet sediment volume and peak discharge is $36 \%$ and $8 \%$, respectively, for the HEM03 set, and 2\% and 30\% for the HEM04 set. With this set of parameters, the model is able to provide values for the cumulative sediment volume of the catchment with an error below $10 \%$. Conversely, a good prediction of the peak discharge could be also obtained by selecting an alternative set of calibrated parameters.

Conversely, event 2 presents higher errors than event 1: $36 \%$ and 14\%, for the sediment outlet volume and peak discharge, respectively, with the HEM03 set, and $12 \%$ and $40 \%$ for the HEM04 set. We have considered more relevant the constraint related with the outlet volume, which in this second event it is also close to the $10 \%$. As remarked before: (i) the magnitude of event 2 is much greater than event 1 and (ii) such flood magnitude may be accompanied by intense sediment transport in the catchment, suggesting that sediment depositional process may occur, ultimately modifying the topography of the catchment and of the river channel. These depositional processes are not included in the source term of the erosion model. Nevertheless, we aim to show that despite of these constraints, the strategy herein outlined is able to provide a useful prediction for the catchment managers at a reasonable computational cost.

Furthermore, and in order to highlight the capabilities of the 2D distributed surface flow, infiltration and erosion models, the sediment concentration along the channel for the event 1 at $t=11925$ min (i.e. at the end of the storm event) is displayed in Figure 13. Two zoom areas are presented for a better illustration of the results. In the lower inset, the zone is located upstream the outlet of the catchment. Some parts of the valley show a higher sediment concentration due the fact that, locally, the topography suffers a depression and the channel narrows, and consequently both the flow velocity and the erosion rate increase. Regarding the upper inset, this zone is located in the outlet of the catchment area. At the end of the watershed, the sediment concentration collected along the whole domain is trapped by the local topography (suddenly the channel becomes wider) and at that point the highest sediment concentration is found. 


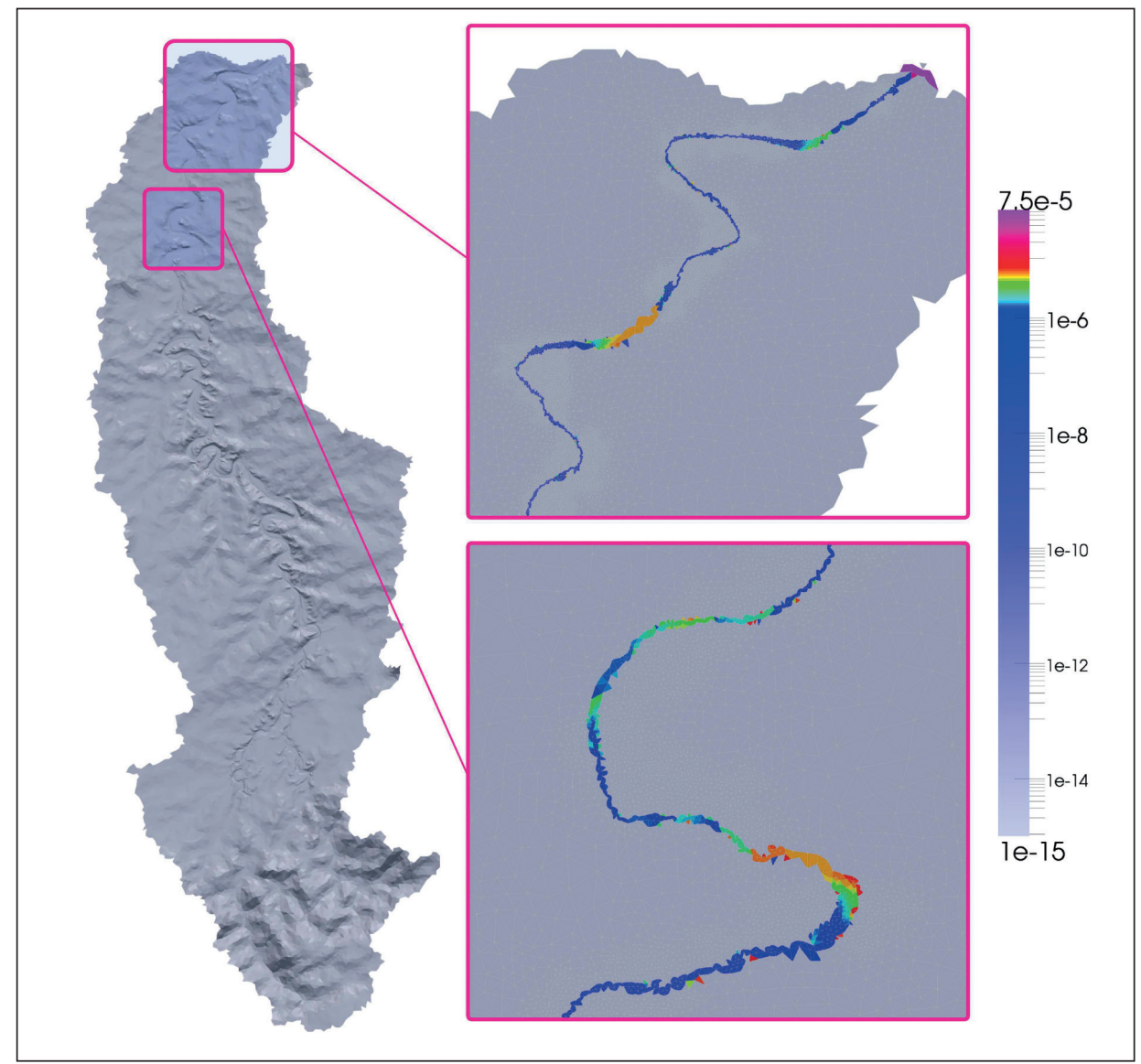

Figure 13. Volumetric sediment concentration (-) along the main channel in the Algars catchment at $t=11925$ min for the event 1 .

\section{Conclusions}

The catchment hydrosedimentary response to a characteristic rainfall event in the Western Mediterranean region has been simulated by means of a distributed surface flow model together with empirical infiltration and erosion laws. Rainfall/runoff losses have been estimated by means of a spatially distributed SCS model as an additional source term for the $2 \mathrm{D}$ shallow water model. The computation of erosion has been done by means of the Hillslope Erosion Model (HEM) using the water depth and flow discharge supplied by the $2 \mathrm{D}$ model at each cell. The calibration process has been divided in two stages. A first approximation based on a simplified catchment model has been proposed in order to get a first approximation of the SCS/HEM parameters. Subsequently, a recalibration was done in the real catchment topography in order to fit the experimental data. The numerical predictions were compared against continuous flow discharge and 
sediment transport concentrations obtained in two sections of the river for two events with different nature (an ordinary flood event and a higher flood event). Conclusions of the work can be drawn as follows:

(i) The SCS model, included as a source term in the 2D shallow water surface flow model, generated accurate results for rainfall/runoff computation since: a) the catchment topography was not complex and did not include steep slopes and cliffy terrains, so just a small fraction of the rainfall was stored in terrain depressions and b) the studied rainfall event was relatively homogeneous through time, so the temporal distribution of the rain (which is ignored by the SCS model) had low impact on the overall modeling performance. Furthermore, the potential of the SCS-CN method was amplified when it was combined with a 2D shallow water flow model since it was thus applied cell by cell (and not to the entire catchment, as lumped methods do) so that the runoff was calculated for each cell in every time step.

(ii) The introduction of the Simplified Catchment Model (SCM) helped in the estimation of the first guess of the SCS/HEM parameters. The computational cost for each simulation in the toy catchment was in the order of seconds (due to the limited amount of cells involved in the computation). This fact allowed to reduce the time required for calibrating the hydrological and morphological parameters of the real catchment.

(iii) Once the rainfall/runoff response was calibrated, sediment transport was simulated to a high degree of precision by means of the HEM combined with the water depth and flow discharge distributed information. The peak load of sediment transport and the cumulative volume of transported sediment were correctly estimated by the model.

Overall, the modeling effort presented here goes beyond the two studied events but opens its application to the analysis of the hydro-sedimentary processes at larger temporal and spatial scales in catchments of similar hydroclimatic characteristics. Altogether our results contribute to the current effort of the scientific community to develop well calibrated scenarios to examine implications of global change to river physical processes, water resources and risk assessment.

\section{Acknowledgments}

This research is supported by the Research Projects CGL2009-09770/BTE, CGL2011-28590 and Consolider Ingenio 2010 CSD2009-00065 funded by the Spanish Ministry of Economy and Competitiveness. Authors acknowledge the support from the Economy and Knowledge Department of the Catalan Government through the Consolidated Research Group 2014 SGR 645 (RIUS-Fluvial Dynamics Research Group). Authors also show gratitude to the Government of Aragón through the Consolidated Research Group T21-Mecánica de Fluidos Computacional. Special thanks are due to the Ebro Basin Water Authority for their collaborative support during the investigation, providing assistance and useful data. The readers can freely access the data from this paper by contacting the corresponding authors (C. Juez, carmelo@unizar.es; A. Tena, alvaro.tena@macs.udl.cat). 


\section{References}

Aksoy, H., Kavvas, M. 2005. A review of hillslope and watershed scale erosion and sediment transport model. Catena 64 (2-3), 247-271. https://doi.org/10.1016/j.catena.2005.08.008.

Aldridge, B., Garrett, J. 1973. Roughness coefficients for stream channels in Arizona. Agency Report, U.S. Geological Survey.

Batalla, R.J., Sala, M. 1996. Impact of land use practices on the sediment yield of a partially disturbed Mediterranean catchment. Zeitschrift für Geomorphologie 107, 79-93.

Brace, W. F. 1980. Permeability of crystalline and argillaceous rocks. International Journal of Rock Mechanics and Mining Sciences 17, 241-251. https://doi.org/10.1016/0148-9062(80)90807-4.

Brath, A., Montanari, A., Toth, E. 2004. Analysis of the effects of different scenarios of historical data availability on the calibration of a spatially-distributed hydrological model. Journal of Hydrology 291 (3-4), 232-253. https://doi.org/10.1016/j.jhydrol.2003.12.044.

Brierley, G.J., Fryirs, KA. 2008. River Futures - An integrative scientific approach to river repair. Island Press, Washington, $328 \mathrm{pp.}$

Bronstert, A. De Araújo J.C., Batalla R.J., Cunha-Costa, A., Delgado J.M., Francke, T., Foerster, S., Guentner A., López-Tarazón, J.A., Mamede, G.L., Medeiros, P.H., Mueller, E., Vericat, D. 2014. Process-based modelling of erosion, sediment transport and reservoir siltation in mesoscale semi-arid catchments. Journal of Soils and Sediments, 14, 2001-2018. http://doi. org/10.1007/s11368-014-0994-1.

Buendía, C., Gibbins, C.N., Vericat, D., Batalla, R.J. 2014. Effects of flow and fine sediment dynamics on the turnover of stream invertebrate assemblages. Ecohydrology 7 (4), 1105-1123. http://doi. org/10.1002/eco.1443.

Buendia, C., Herrero, A., Sabater, S., Batalla, R.J. 2016. An appraisal of the sediment yield in Western Mediterranean basins. Science of the Total Environment 572, 538-553. http://doi.org/10.1016/j. scitotenv.2016.08.065.

Bussi, G., Francés, F., Horel, E., López-Tarazón, J.A., Batalla, R.J. 2014. Modelling the impact of climate change on sediment yield in a highly erodible Mediterranean catchment. Journal of Soils and Sediments 14, 1921-1937. http://doi.org/10.1007/s11368-014-0956-7.

Bussi, G., Francés, F., Montoya, J., Julien, P. 2014. Distributed sediment yield modelling: Importance of initial sediment conditions. Environmental Software and Modelling 58, 58-70. https://doi. org/10.1016/j.envsoft.2014.04.010.

Caviedes-Voullième, D., García-Navarro, P., Murillo, J. 2012. Influence of mesh structure on 2D full shallow water equations and SCS Curve Number simulation of rainfall/runoff events. Journal of Hydrology 448-449, 39-59. https://doi.org/10.1016/j.jhydrol.2012.04.006.

Chow, V. 1959. Open-channel hydraulics. McGraw-Hill, 680 pp.

Conacher A.J., Sala, M. 1998. (Eds.). Land Degradation in Mediterranean Environments of the World: Nature and Extent, Causes and Solutions. Wiley, Chichester, 520 pp.

Costabile, P., Costanzo, C., Macchione, F. 2012. Comparative analysis of overland flow models using finite volume schemes. Journal of Hydroinformatics 14 (1), 122-135. http://doi.org/10.2166/ hydro.2011.077. European Commission, 1994. CORINE Land Cover.

European Commission, 1994. CORIME Land Cover.

Davis, S.N. 1969. Porosity and permeability of natural materials. In: R. De Wiest (Ed.), Flow Through Porous Media. Academic Press, New York, pp. 54-90.

Delgado, J., Llorens, P., Nord, G., Calder, I.R., Gallart, F. 2010. Modelling the hydrological response of a Mediterranean medium-sized headwater basin subject to land cover change: The Cardener River basin (NE Spain). Journal of Hydrology 383, 125-134. https://doi.org/10.1016/j. jhydrol.2009.07.024.

Feng, K., Molz, F. 1997. A 2-D diffusion-based, wetland flow model. Journal of Hydrology 196, 230250. https://doi.org/10.1016/S0022-1694(96)03282-9. 
Fernández-Pato, J.,Caviedes-Voullième,D., García-Navarro, P. 2016. Rainfall/runoff simulation with 2D full shallow water equations: Sensitivity analysis and calibration of infiltration parameters. Journal of Hydrology 9, 496-513. https://doi.org/10.1016/j.jhydrol.2016.03.021.

Francke, T., López-Tarazón, J.A., Vericat, D. Bronstert, A., Batalla, R.J. 2008. Flood-based analysis of high-magnitude sediment transport using a non-parametric method. Earth Surface Processes and Landforms 33 (13), 2064-2077. http://doi.org/10.1002/esp.1654.

Freeze, R., Cherry, J. 1979. Groundwater. Prentice-Hall, Englewood Cliffs, 604 pp.

Gallart, F., Amaxidis, Y., Botti, P., Cane, G., Castillo, V., Chapman, P., Froebrich, J., García-Pintado, J., Latron, J., Llorens, P., Lo Porto, A., Morais, M., Neves, R., Ninov, P., Perrin, J., Ibarova, I., Skoulikidis, N., Tournoud, M. 2008a. Investigating hydrological regimes and processes in a set of catchments with temporary waters in Mediterranean Europe. Hydrological Sciences Journal 53, 618-628. https://doi.org/10.1623/hysj.53.3.618.

Gallart, F., Latron, J., Llorens, P. Beven, K.J. 2008b. Upscaling discrete internal observations for obtaining catchment-averaged TOPMODEL parameters in a small Mediterranean mountain basin. Physics and Chemistry of the Earth 33, 17-18. https://doi.org/10.1016/j.pce.2008.03.003.

García-Ruiz, J.M. 2010. The effects of land uses on soil erosion in Spain: a review. Catena 81, 1-11. https://doi.org/10.1016/j.catena.2010.01.001.

García-Ruiz, J.M. Poesen, J. 2007. Soil erosion and sediment transport under different land use/land cover scenarios. Catena 71 (1), 1. https://doi.org/10.1016/j.catena.2006.05.012.

Gumière, S.J., Bailly, J., Cheviron, B., Raclot, D., Le Bissonnais, Y., Rousseau, A.N. 2014. Evaluating the Impact of the Spatial Distribution of Land Management Practices on Water Erosion: Case Study of a Mediterranean Catchment. Journal of Hydrologic Engineering 20 (6). http://doi. org/10.1061/(asce)he.1943-5584.0001076.

Harmon, R., Doe W, W. 2001. Landscape Erosion and Evolution Modelling. Kluwer Academic, New York.

Herrero, A., Buendía, C., Bussi, G., Sabater, S., Vericat, D., Palau, A. Batalla, R.J. 2017. Modelling the hydrosedimentary response of a large Pyrennean catchment to global change. Journal of Soils and Sediments 17, 2677-2690. http://doi.org/10.1007/s11368-017-1684-6.

Jetten, V., de Roo, A., Favis-Mortlock, D. 1999. Evaluation of field-scale and catchment-scale soil erosion models. Catena 37 (3-4), 521-541. https://doi.org/10.1016/S0341-8162(99)00037-5.

Juez, C., Murillo, J., García-Navarro, P. 2014. A 2D weakly-coupled and efficient numerical model for transient shallow flow and movable bed. Advances in Water Resources 71, 93-109. https:// doi.org/10.1016/j.advwatres.2014.05.014.

Lane, L. Nichols, M., Paige, G. 1995. Modelling erosion on hillslopes: concepts, theory and data. In: P. Binning, H. Bridgman, B. Williams (Eds.), Agriculture, Catchment Hydrology and Industry, University of New Castle, New Castle, pp. 1-7.

Lehner, B., Doll, P., Alcamo, J., Henrichs, T., Kaspar, F. 2006. Estimating the impact of global change on flood and drought risks in Europe: A continental integrated analysis. Climatic Change 75, 273-299. http://doi.org/10.1007/s10584-006-6338-4.

LeVeque, R. J. 2002. Finite Volume Methods for Hyperbolic Problems. Cambridge University Press, New York, 558 pp.

Manning, R. 1895. On the flow of water in open channels and pipes. Transactions of the Institution of Civil Engineers of Ireland 20, 161-207.

Mariani, L., Parisi, S.G. 2014. Extreme rainfalls in the Mediterranean area. In: N. Diodato, G. Bellocchi (Eds.), Storminess and environmental change, advances in natural and technological hazards research. Springer, Dordrecht, pp. 17-37.

Merritt, W., Letcher, R., Jakeman, A. 2003. A review of erosion and sediment transport models. Environmental Modelling and Software 18 (8), 761-799. https://doi.org/10.1016/S13648152(03)00078-1. 
Molina-Navarro, E., Martínez-Pérez, S., Sastre-Merlín, A., Bienes-Allas, R. 2014. Hydrologic modeling in a small Mediterranean Basin as a tool to assess the feasibility of a limno-reservoir. Journal of Environmental Quality 43 (1), 121-131. http://doi.org/10.2134/jeq2011.0360.

Mullan, D., Favis-Mortlock, D., Fealy, R. 2012. Addressing key limitations associated with modelling soil erosion under the impacts of future climate change. Agricultural and Forest Meteorology 156, 18-30. https://doi.org/10.1016/j.agrformet.2011.12.004

Murillo, J., García-Navarro, P. 2010. Weak solutions for partial differential equations with source terms: Application to the shallow water equations. Journal of Computational Physics 229, 4327-4368. https://doi.org/10.1016/j.jcp.2010.02.016.

Murillo, J., García-Navarro, P. 2011. Improved Riemann solvers for complex transport in twodimensional unsteady shallow flow. Journal of Computational Physics 230, 7202-7239. https:// doi.org/10.1016/j.jcp.2011.05.022.

Nadal-Romero, E., González-Hidalgo, J.C., Cortesi, N., Desir, G., Gómez, J.A., Lasanta, T., Lucía, A., Marín, C., Martínez-Murillo, J.F., Pacheco, E., Rodríguez-Blanco, M.L., Romero Díaz, A., Ruiz-Sinoga, J.D., Taguas, E.V., Taboada-Castro, M.M., Taboada-Castro, M.T., Úbeda, X., Zabaleta, A. 2015. Relationship of runoff, erosion and sediment yield to weather types in the Iberian Peninsula. Geomorphology 228, 372-381. https://doi.org/10.1016/j. geomorph.2014.09.011.

Nord, G., Esteves, M. 2010. The effect of soil type, meteorological forcing, and slope gradient on the internal erosion processes at the local scale. Hydrological Processes 24 (13), 1766-1780. http:// doi.org/10.1002/hyp.7613.

Owens, P. 2005. Conceptual models and budgets for sediment management at the river basin scale. Journal of Soils and Sediments 5, 201-212. https://doi.org/10.1065/jss2005.05.133.

Ponce, V. 1986. Diffusion wave modeling of catchment dynamics. Journal of Hydraulic Engineering 112, 716-727. https://doi.org/10.1061/(ASCE)0733-9429(1986)112:8(716).

Rai, R.K., Mathur, B.S. 2007. Event-based soil erosion modeling of small watersheds. Journal of Hydrologic Engineering 12 (6), 559-572. https://doi.org/10.1061/(ASCE)10840699(2007)12:6(559).

Rovira, A., Batalla, R. 2006. Temporal distribution of suspended sediment transport in a Mediterranean basin: the Lower Tordera (NE SPAIN). Geomorphology 79, 58-71. https://doi.org/10.1016/j. geomorph.2005.09.016.

Sarkar, R., Dutta, S., Panigrahy, S. 2008. Characterizing overland flow on a preferential infiltration dominated hillslope: Case study. Journal of Hydrologic Engineering 13 (7), 563-569. https:// doi.org/10.1061/(ASCE)1084-0699(2008)13:7(563).

Schleiss, A.J., Franca, M.J., Juez, C., De Cesare, G. 2016. Reservoir sedimentation. Journal of Hydraulic Research 54, 595-614. https://doi.org/10.1080/00221686.2016.1225320.

Shyrley, E., Lane, L. 1978. A sediment yield equation from an erosion model. Hydrology and Water Resources in Arizona and the Southwest 8, 90-96.

Tena, A., Batalla, R., Vericat, D., López-Tarazón, J. 2011. Suspended sediment dynamics in a large regulated river over a 10-year period (the lower Ebro, NE Iberian Peninsula). Geomorphology 125, 73-84. https://doi.org/10.1016/j.geomorph.2010.07.029.

USDA 1986. Urban hydrology for small watersheds. Environment Agency Report, United States Department of Agriculture (USDA).

Verdú, J.M., Batalla, R.J., Poch, R.M. 2000. Dinámica erosiva y aplicabilidad de modelos físicos de erosión en una cuenca de montaña Mediterránea (Ribera Salada, cuenca del Segre). Pirineos 155, 37-57. http://doi.org/10.3989/pirineos.2000.v155.87.

Wigmosta, M., Lane, L., Tagestad, J., Coleman, A. 2009. Hydrological and erosion models to assess land use and management practices affecting soil erosion. Journal of Hydrologic Engineering 14 (1), 27-41. https://doi.org/10.1061/(ASCE)1084-0699(2009)14:1(27). 